\title{
New Histories of the End of
}

\section{the Cold War and the Late}

\section{Twentieth Century}

\section{A R T E M Y M. K A L I N O V S K Y}

Gregory F. Domber, Empowering Revolution: America, Poland, and the End of the Cold War (Chapel Hill: University of North Carolina Press, 20I4), 4I6 pp., \$39.95 ISBN 978-I-4686-I85I-7

James Graham Wilson, The Triumph of Improvisation: Gorbachev's Adaptability, Reagan's Engagement, and the End of the Cold War (Ithaca: Cornell University Press, 20I4) 280 pp., \$29.95 ISBN 978-0-80I4-5683-I

Robert Service, The End of the Cold War: 1985-1991 (New York: Public Affairs, ISBN 643 pp., \$35.00 978-0-2307-4808-8

Mary Elise Sarotte, The Collapse: The Accidental Opening of the Berlin Wall. (New York: Basic Books, 20I4). 320 pp. \$27.99 (cloth), ISBN 978-0-465-06494-6.

Mary Elise Sarotte, 1989: The Struggle to Create Post-Cold War Europe (updated, with a new afterword by the author) (Princeton: Princeton University Press, 20I4). 376 pp., \$I9.95 ISBN: 978-0-69II-637I-O

The twentieth anniversary of communism's collapse in Eastern Europe saw a torrent of new publications on those momentous events. In an essay for the New York Review of Books Timothy Garton Ash complained that for all the work that has gone into explaining the transitions of that year 'we have learned little new about the causes and social dynamics of the mass, popular actions that actually gave 1989 a claim to be a revolution, or chain of revolutions'. ${ }^{1}$ Yet what is striking about that older literature from the vantage point of 2016 is not the dominant focus on high politics but that scholars in 2009 wrote confidently about the forward progression from communist collapse to liberal democracy and European integration. Nationalism and socialism were seen as (mostly) ideas of the past. NATO had incorporated most of the former Warsaw pact. The Arab Spring was welcomed as part of the international turn toward democracy and away from authoritarianism. Russia might not have been happy with

Faculty of European Studies, University of Amsterdam, Kloveniersburgwal 48, Amsterdam IoI2 CX Netherlands; a.m.kalinovsky@uva.nl

1 A good overview of the literature from that year is Timothy Garton Ash, 'I989!', New York Review of

Books, 5 Nov. 2009 .

Contemporary European History, 27, I (2018), pp. I49-I6I. (C) The Author(s) 2017. This is an Open Access article, distributed under the terms of the Creative Commons Attribution-NonCommercial-NoDerivatives licence (http://creativecommons. org/licenses/by-nc-nd/4.0/), which permits non-commercial re-use,distribution, and reproduction in any medium, provided the original work is unaltered and is properly cited. The written permission of Cambridge University Press must be obtained for commercial re-use or in order to create a derivative work. 
the state of the world, but in 2009 Putin seemed to be working with the existing reality.

Eight years later things look very different. Russia has invaded Ukraine and challenged NATO expansion, a number of Eastern European countries have elected radical nationalists to power and the Middle East has become embroiled in civil wars that have sparked a global migration crisis. Russia has shown through its military acts and its international propaganda that it is no longer satisfied with grumbling from the sidelines or passively accepting the United States in its neighborhood and beyond. Donald Trump's election as the forty-fifth president of the United States has been accompanied by allegations of Russian meddling in the campaign. These problems were decades in the making, however, and can all be traced back to differing interpretations of what happened in I989/I99I. Soviet leaders believed in I99I that they were negotiating a peaceful end to decades of tensions. Their narrative of negotiation and peaceful transition stood in stark contrast to that of Western officials, who used their claim that they 'won' the Cold War to push post-Soviet Russia off the world stage.

Meanwhile, while pundits have been busy proclaiming a 'New Cold War', the late Cold War is having something of a moment in popular culture. The plot of Jonathan Franzen's 20I5 bestseller Purity revolves around the collapse of the German Democratic Republic in 1989. In the United States two of the most highly acclaimed shows of recent years, The Americans and Stranger Things, are set in the first half of the I980s. The German series Deutschland-83 tells the story of an East German army conscript infiltrated into West Germany to spy on NATO planning for new missile systems. Curiously, all three of these programmes, while developed against the background of growing tensions between Russia and NATO countries (and, in the case of The Americans, inspired by a recent spy case) take a very skeptical and often tragic view of the whole Cold War enterprise and its justifications by both superpowers. One can only speculate whether current tensions are pushing viewers towards these shows - their popularity, however, suggests that fascination with the period and its legacy is not going away anytime soon.

The studies under review in this essay all address this new reality, even if indirectly. All of them contribute to our understanding of how the Cold War ended, and on what terms - a dispute that remains at the centre of Russian-US relations. More broadly, the studies analysed in this article ask us to revisit what happened in 1989 and think critically about trust as a category of analysis. While quite different in methodology, focus and tone, all wrestle with the reasons why, after a decade of détente in East-West relations, trust was at a nadir in the early I980s. They also investigate how the absence of trust shaped the events of the late I980s and left a profound imprint on post-Cold War relations. These books, together, suggest that there was no predetermined outcome in I989: superpower diplomacy, domestic politics, protest and transnational organisation all shaped the events of that year, and each could have shifted global dynamics in a different direction.

These studies thus join and expand upon a new school of Cold War historiography, one that emphasises transnational activism and the appeal to universalist notions like 
human rights in this period. ${ }^{2}$ Standard English language interpretations of the end of the Cold War can be roughly grouped into five categories. First are studies that focus on US initiative, emphasising either the importance of Ronald Reagan's willingness to vigorously challenge the Soviet Union, in Afghanistan and beyond, and thus force it to undertake reform in domestic and foreign politics, or Reagan's flexibility and willingness to partner with the reformist leader Mikhail Gorbachev to sign a number of agreements on nuclear issues and build trust. ${ }^{3}$ A second camp emphasises the role of Gorbachev and Soviet politicians in seeking an end to confrontation because of a sincere belief in the need to eliminate the threat of nuclear war and resolve conflicts in the Third World. ${ }^{4}$ A third interpretation focuses on the European theatre, in particular the centrality of the German question for Western and Socialist Bloc politicians. ${ }^{5}$ The fourth strand focuses on longer term structural factors, such as socialist states' ballooning debt to Western European countries; this debt was acquired in an attempt to modernise socialist economies but ultimately left them dependent on their adversaries and constricted in their policy options at home. ${ }^{6}$ The newly emerging school of analysis, in which we can place the books at the centre of this review, combines a multi-archival approach that includes transnational actors and grassroots movements without losing sight of power politics and diplomacy.

\section{Rethinking US Relations with Eastern Europe}

Gregory F. Domber's Empowering Revolution: America, Poland, and the End of the Cold War explores the impact of US involvement in the period between the rise and crushing of the Solidarity movement in 1982 and the roundtable talks which ultimately ended communist rule in I989. Having mined Polish and US archives and conducted dozens of interviews, Domber integrates the story of diplomatic relations between the United States and Poland in the I980s with analysis of Solidarity's

2 For a summary of the debate, see Artemy M. Kalinovsky and Craig Daigle, 'Explanations for the End of the Cold War', in Artemy M. Kalinovksy and Craig Daigle, eds., The Routledge Handbook of the Cold War (Abdingdon: Routledge, 20I4), 37I-87. An important early entry in the 'transnational' approach was Matthew Evangelista's Unarmed Forces: The Transnational Movement to End the Cold War (Ithaca: Cornell University Press, I999).

3 See, for example: Paul Kengor, The Crusader: Ronald Reagan and the Fall of Communism (New York: Harper, 2006); Peter Schweizer, Reagan's War: The Epic Struggle of His Forty Year Struggle and Final Triumph Over Communism (New York: Doubleday, 2002); John Lewis Gaddis, Strategies of Containment: A Critical Appraisal of American National Security Policy During the Cold War, revised and expanded edition (New York: Oxford University Press, 2005).

4 Including: Archie Brown, 'Perestroika and the End of the Cold War', Cold War History, 7, I (Feb. 2007), I-I7 and Melvyn P. Leffler, For the Soul of Mankind: The United States, the Soviet Union, and the Cold War (New York: Hill and Wang, 2007).

5 Michael Cox, 'Another Transatlantic Split? American and European Narratives and the End of the Cold War', Cold War History, 7, I (Feb. 2007): I2 I-46.

${ }^{6}$ Stephen G. Brooks and William C. Wohlforth, 'Economic Constraints and the Turn towards Superpower Cooperation in the I980s', in Olav Njølstad, The Last Decade of the Cold War: From Conflict Escalation to Conflict Resolution (London: Frank Cass, 2004), 69-98. See also, Brooks and Wohlforth, 'Clarifying the End of Cold War Debate', Cold War History, 7, 3 (Aug. 2007): 447-54. 
transnational links, which helped to sustain the movement. Domber's broader aim, as he puts it, is to "synthesise disparate debates on the nature of Western influence and the end of the Cold War by highlighting where Soviet reforms created space for change in Eastern Europe and rejecting claims of any direct American responsibility for the collapse of Communism' (3). Domber acknowledges the part US policies played in supporting Solidarity and other activists in the I980s but argues that local Polish actors played the crucial role in sustaining resistance.

Domber is particularly sensitive to the dilemmas faced by Poland's communist leader in this period, General Wojciech Jaruzelski. In I98I Jaruzelski decided to impose martial law, partly to prevent a Soviet intervention, partly to consolidate his own rule. The United States responded with sanctions and a rebuke of the Polish leader. Domber describes how Jaruzelski was incredulous that the US government did not seem to appreciate the fact that he had saved his country, including the opposition, from a much worse fate. He spoke of US sanctions as a 'betrayal' (I756). As a result, Poland and the United States stopped exchanging ambassadors and relations cooled. In Warsaw Polish security officials harassed American diplomats and Polish visitors to the small library attached to the US embassy (95-6). Domber suggests that the Reagan administration was constrained by its own harsh rhetoric on communism and its earlier promise to promises to prosecute the Cold War.

Because neither state was willing to budge, Non Governmental Organisations (NGOs) stepped in to play a more important role in providing aid to Poland and maintaining contact with dissidents. In the I970s sceptics of the US-Soviet détente, pursued under two Republican administrations, could be found among both Democrats and Republicans. Many détente sceptics threw their energy into the proliferation of human rights organisations and NGOs, some of them working on Eastern Europe. As Sarah Snyder argues in her 20II book, Human Rights Activism and the End of the Cold War: A Transnational History of the Helsinki Network, the signing of the Helsinki Accords in I975 created the basis for a transnational network, operating within the socialist countries and abroad, to monitor and where possible challenge human rights abuses. The Soviets had signed the agreement because it fulfilled their long-held dreams of recognised existing borders in Europe; they did not take the provisions on human rights very seriously. Ironically, however, the agreement that secured the borders of the Soviet Bloc actually opened up the socialist states to potentially more interference from abroad, at least insofar as it established institutions for the monitoring of domestic human rights situations by international observers. Whether one accepts Snyder's argument that US support for the human rights movements was motivated by genuine interest in these issues, or whether one adopts the more cynical view that human rights became a cudgel against socialist governments, used to enhance US power, it is clear that the change in how diplomacy was conducted was significant. ${ }^{7}$

7 More skeptical accounts include Samuel Moyn, The Last Utopia: Human Rights in History (Cambridge, MA: Harvard University Press, 20Iо). For a very useful overview see Stefan-Ludwig Hoffman, 'Human Rights and History', Past and Present (July 20I6, online first). 
Domber describes how these NGO's joined transnational trade unions and the Catholic church in Poland, aiding the opposition and providing economic assistance to the beleaguered government in areas such as health care. Domber agrees that these organisations played a role in Jaruzelski's Poland but demonstrates the limits of their independence from high politics in the Cold War context. After all, a significant portion of their funding came from the US government via agencies like the National Endowment for Democracy, itself founded in 1983 with the express purpose of promoting democracy abroad (89). Domber's work contextualises US policy towards both Poland and Eastern Europe as a whole, during a period in which the state's near monopoly on foreign affairs was increasingly challenged by non-state organisations and transnational networks. Domber's persuasive account helps us better understand the mechanics of the 'transnational network', which helped sustain the Polish resistance throughout the I980s, and that network's connection to larger shifts in the international relations of the late Cold War. Domber's ability to integrate the story of Polish civil society with a careful study of US foreign policy should serve as a model for further histories of the I980s and the links between social movements and power politics.

\section{Beyond Reagan and Gorbachev}

The legacy of Reagan and Gorbachev continues to loom large in academic studies and the popular perception of the End of the Cold War, and with good reason - the two men were symbols of great changes to millions in their countries and beyond while they were still in power, and they expanded significant political capital to change the course of the Cold War. Nevertheless, an excessive focus on these 'great men' can blind us to the deeper structural problems the two superpowers and their allies faced in the I980s, as well as the complexity of turning institutions, bureaucracies and publics towards a new foreign policy paradigm.

In the United States, understanding of the Reagan administration and its foreign policy has increased markedly in recent years, thanks, in part, to the gradual opening of materials in the Ronald Reagan Presidential Library, as well as works that have drawn attention to how the various domestic and international shocks of the I970s continued to influence the politics of the decade that followed. ${ }^{8}$ There has been little academic research on the 'Gorbachev phenomenon' in post-Soviet Russia. Much of the Russian literature is in the form of memoirs, rather than scholarly analysis. Gorbachev's advisers, supporters and detractors began weighing in with memoirs even before the Soviet Union collapsed, and Gorbachev himself has continued to

\footnotetext{
${ }^{8}$ Sean Wilentz, The Age of Reagan: A History, 1974-2008 (New York: Harper Collins, 2008); Niall Ferguson, Charles S. Maier, Erez Manella and Daniel J. Sargent, eds., Shock of the Global: The 1970s in Perspective (Cambridge, MA: Harvard University Press, 20II); Thomas Borstleman, The 1970s: A New Global History from Civil Rights to Economic Inequality (Princeton, PA: Princeton University Press, 20I2); Daniel J. Sargent, A Superpower Transformed: The Remaking of American Foreign Relations in the 1970s (New York: Oxford University Press, 2015).
} 
actively shape memory of his legacy. ${ }^{9}$ With important exceptions, including Jack Matlock's memoir, Reagan and Gorbachev, most accounts focus on the effort of one or the other leader. ${ }^{10}$ By contrast, the books by James Graham Wilson and Robert Service are notable for focusing on the interaction between these two leaders and the political context in which they had to work.

In examining the chief protagonists of the end of the Cold War - Reagan, Gorbachev, George H.W. Bush and their key advisers and emissaries - James Graham Wilson's The Triumph of Improvisation: Gorbachev's Adaptability, Reagan's Engagement, and the End of the Cold War, argues that neither the United States nor the Soviet Union had a master plan to win or end the Cold War. Rather, Wilson argues, Reagan and Gorbachev both shared a commitment to improving ties but had to be flexible in finding ways to get to that goal. Both leaders had to reassess their own notions of the main adversary and pull their own often reluctant subordinates along on the journey. The outlines of this story have been known for some time, but Wilson's book makes important advances in helping us understand the dynamics of Soviet-US relations and the realities of domestic and intra-administration politics, particularly on the US side. $^{11}$

Since Beth Fischer's The Reagan Reversal: Foreign Policy and the End of the Cold War, historians have generally accepted that Reagan's engagement with the Soviets after I984 was not the result of purely Soviet initiatives or of domestic politics but also the US president's own decision to follow a new course. In the early years of his presidency Reagan listened to his most militant advisers, such as Alexander Haig, who were intent on pursuing a hard line with the Soviets. These lost years supposedly came to an end in I984, when Reagan gave his famous 'Ivan and Anya' speech, pointing out that Soviet people were just like Americans and that there was fundamentally no reason why the two powers could not live in peace. Wilson adds nuance to this narrative by pointing to Reagan's commitment to finding a new way to work with Moscow - based in part on his genuine fear of nuclear weapons from a much earlier date. The problem, as Wilson sees it, was how to get there. Reagan did not like personal confrontation, and when hardliners like Haig dragged his administration in a direction the president did not want to go, he was loathe to reprimand, let alone fire, them. These internal conflicts were compounded by Reagan himself, who believed that he could continue fighting communism around the world, including in South America, while also reaching a new understanding with the Soviets (34-6).

Among the strongest chapters of Wilson's book is one that deals with the aftermath of the Iran-Contra scandal, which hurt the president's public image and threatened to undermine his efforts to reach agreements with Moscow on nuclear issues. The

9 See Vladislav M. Zubok, 'Gorbachev and the End of the Cold War: Perspectives on History and Personality', Cold War History, 2, 2 (2002), 6I-IoO.

${ }^{10}$ Jack F. Matlock Jr. Reagan and Gorbachev: How the Cold War Ended (New York: Random House, 2004).

11 See, for example, Vladislav M. Zubok, A Failed Empire: The Soviet Union in the Cold War from Stalin to Gorbachev (Chapel Hill: University of North Carolina Press, 2009); Jack Matlock, Reagan and Gorbachev: How the Cold War Ended (New York: Random House, 2004). 
scandal revealed chaos within the administration and suggested that Reagan was not in control of his ship. At the same time, conservatives remained uncomfortable with Reagan's outreach to the Soviets. Reagan stuck with his secretary of state, George Shultz, despite repeated calls to have him fired after Iran-Contra. Shultz, who was building a personal rapport with the Soviet Foreign Minister Eduard Shevardnadze, was crucial for any peace-deal, and Reagan's willingness to stand by his Secretary of State, against the advice of adversaries and many allies, may have saved the Intermediate-Range Nuclear Forces Treaty agreed in I987. (I3I-5). While Wilson pays attention to the Soviet side of the story, highlighting some similarities and differences in the challenges both leaders faced, his real insights are on the US side.

By contrast, Robert Services's The End of the Cold War, 1985-1991 gives similar weight to both Washington and Moscow, but the real insights in this book come on the Soviet side. (Service and Wilson both work with English and Russian sources.) Service's account, at 63I pages including the notes and index, is to date the most detailed archivally-grounded study of Soviet-American diplomacy in the late Cold War. (Although Raymond Garthoffs works, meticulous but written without the benefit of archival sources available to historians today, will remain an important resource to students of the period for some time to come.) ${ }^{12}$ Service impressively integrates a host of previously unpublished sources from Soviet officials, in particular tapping the holdings of the Hoover Institution at Stanford University.

Like Wilson, Service is interested in the ways that US and Soviet officials improvised their way through almost a decade of diplomacy. Although Service nods to questions of long-term problems and ideas in the introduction, his primary interest is the day to day work of politics and diplomacy. The book focuses on how these leaders sought ways to work with each other and build the trust necessary to pull their countries from the peak of the tensions of the first half of the I980s and to ultimately end the Cold War. This is a story of changing mutual perceptions, the 'intangibles' of diplomacy and the challenges of bringing one's erstwhile supporters, bureaucracies and allies along for radical reform. The least explored material that Service uses comes from the diaries and notes of second tier officials like Teimuraz Stepanov-Abuladze, a deputy of Soviet Foreign Minister Eduard Shevardnadze, and Anatoly Adamishin, a deputy Foreign Minister. The strongest parts of the book address the Soviets' policy process: for example, one chapter reveals how the Soviet security establishment had to be recruited to support Soviet concessions in the treaty on Intermediate Range Nuclear Forces (28I-4).

The Cold War was about alliance politics. Sustaining the conflict meant convincing elites and, to whatever extent possible, publics at home and abroad that the adversary (socialism, capitalism) presented a real danger. What these books also highlight is that maintaining a consensus was growing increasingly difficult for both sides. In the West, the wars in Indochina and the protest movements of the late I960s and I970s had

12 Raymond Garthoff, The Great Transition: American-Soviet Relations and the End of the Cold War (Washington, DC: Brookings Institution Press, 1994). 
helped collapse an earlier domestic consensus on the containment of communism. Nuclear weapons complicated these issues. On the one hand, they highlighted the danger caused by the enemy. On the other, they were a constant demonstration of the folly of the Cold War. The plan to place medium-range nuclear missiles in Europe was met with widespread protests. Allies disagreed on how to respond to the US invasion of Afghanistan and martial law in Poland. The US grain embargo against the Soviet Union after the invasion of Afghanistan proved difficult to sustain, as US allies were eager to restart grain exports to the Soviet Union. They refused sanctions on Poland. Washington wanted to prevent the building of a pipeline that would transport Siberian gas to European industries, but, as Wilson shows, even the most stalwart European allies like the United Kingdom were not eager to go along with the Reagan administration's plans. Even if something of the 'early Cold War' consensus had been re-established domestically in the early I980s, it was not there among Washington's European allies.

And what about on the Soviet side? The elites were obviously in a tricky spot. Several of the socialist states, with encouragement from Moscow, had taken out major loans in the West during the détente era in the hopes of modernising their industries. These loans failed to transform the borrowers into export powerhouses, and when the loans came due in the early I980s they found themselves in very difficult circumstances. This did not stop the regimes from cracking down when they felt it necessary. Arguably, the Cold War confrontation of the early I980s made this easier, as it allowed the socialist regimes to justify lower living standards and political repression. But reading Domber one gets the sense that Jaruzelski, at least, found the new Cold War tensions a nuisance rather than a political opportunity. He would have much preferred access to Western loans and aid to introducing martial law. After meeting the newly-installed General Secretary Yurii Andropov in I983, Jaruzelski finally felt he might have more breathing room to handle domestic problems and relations with the West, a development also welcomed by Hungarian leaders (IO2).

By I988, of course, this situation had changed considerably. Gorbachev had made it clear that the Eastern European regimes could not rely on Soviet intervention (or financial support) to stay in power. To recover living standards, therefore, they would have to engage with their Western creditors; and if they were to hope for any kind of leniency they would need to take western concerns about human rights into account - issues that had grown in importance in international politics since the late I970s. This conjuncture was a crucial part of the background to the momentous events of I989, just as Gorbachev unmade the remaining Cold War consensus faster than many of his allies were willing to accept.

Ending the Cold War required establishing a new consensus, which, as the books by Wilson, Service and Domber show, was far from straightforward. Eastern European socialist leaders had had agency throughout the Cold War, and at the end of it some used it to try to stop Gorbachev's reform. Among them was Erich Honecker, who had led the East German Socialist Unity Party since ousting Walter Ulbricht in I97I. Honecker, who had kept borrowing money from West German banks but refused to listen to Soviet advice about reform, was a giant thorn in Gorbachev's 
side. Some of the most fascinating discussions in Service's book concern the efforts by Gorbachev and his emissaries to prevent Honecker, as well as other sceptical East European leaders like Czechoslovakia's Husak and Bulgaria's Todor Zhivkov, from undermining their diplomacy without completely alienating them at the same time $(320-8)$.

\section{9: Top-Down and Bottom-Up}

The fall of the East German socialist regime and the subsequent reunification of Germany has been the subject of two outstanding books by Mary Elise Sarotte. Sarotte is the rare historian who can operate equally well in several different keys. In 1989: The Struggle to Create Post-Cold War Europe, she explored politics and diplomacy behind the reunification of the two Germanies. Five years later she followed up with The Collapse: The Accidental Opening of the Berlin Wall (New York: BasicBooks, 20I4). The first is an exemplary work of political and diplomatic history, drawing on archival research in Germany and the United States, as well as oral history. (The 2014 edition, released for the twenty-fifth anniversary, incorporates US sources Sarotte received after completing the original manuscript and includes a new afterword.) The second does not neglect the politics but is very much a story from below - it draws on extensive oral history with dissidents, protesters, officials and other eyewitnesses in the former East Germany to reconstruct the events that led to the downfall of Honecker and the (accidental) opening of the wall in November 1989.

Indeed, some of the best works on the revolutions of 1989 have focused on grassroots activism and mobilisation. ${ }^{13}$ Others, such as Steve Solnick or Stephen Kotkin and Jan Gross, have focused on the turn of the crucial 'middle' - party members and managers who abandoned the socialist system. Sarotte goes further, however. Taken together, her two books explore the interplay between social dynamics, institutional struggle and international relations. While many accounts of the revolutions of 1989 have taken protest and dissent as crucial components of what happened, Sarotte's is unique in combining a forensic account of events with an analysis of wider developments. ${ }^{14}$

The Collapse follows a group of dissidents through the organisations and associations that helped them maintain cohesion over the course of the I980s. Focusing on a number of key individuals, Sarotte is able to reconstruct their life histories and explain how they came to be where they were in I989. She then integrates the regime's reactions and policy responses, uncovering the interplay between the erosion of the regime's confidence and the actions and trajectories of the protest movement in the city of Leipzig from the late summer of 1989 . Sarotte is able to write sympathetically

13 Padraic Kenney, A carnival of revolution: Central Europe 1989. Princeton University Press, 2002.

14 Kenney's 2002 classic, cited above, casts a wider net over the region, but focuses almost exclusively on youth movements and does not engage in the kind of forensic breakdown of events that Sarotte executes here. Sarotte is also drawing on a wider secondary literature in German when discussing the events leading up to the wall. 
about the regime's supporters as well as its opponents. Among the most poignant moments in the book is her description of the dilemma faced by Harald Jäger, the guard in charge of the Bornholmer border crossing on that fateful night in November I989. When the party media secretary Schabowski accidentally announced the immediate opening of the wall, officials like Jäger were forced to improvise. As crowds gathered, he decided to let the worst troublemakers through and stamp their papers in a way that meant they would be denied re-entry. But then he realised that some of those who had crossed had left sleeping children behind, so Jäger made an exception for the distraught parents. At that point, Sarotte writes: 'Jäger felt that, having already taken a few steps towards disobedience, he might as well take a few more [and let the other protesters back in]. The thought crossed his mind that he ought to at least tell [his superior officer] Ziegenhorn what he had just done, but then he thought, why bother?' (I44). The chapter works so powerfully because we see the events develop hour by hour from so many different perspectives, and Sarotte is able to write with sufficient empathy to make the drama of all these actors' actions palpable.

A strength of Sarotte's work is her willingness to consider alternatives to the developments with which we are familiar. Accounts of German reunification generally skip over the various options that were on the table in I989 and I990. While it is well known that reunification had its sceptics among British, French, American and Soviet leaders, as well as within Western Germany, the alternatives considered by East Germans themselves are usually given short shrift. Yet, as Sarotte makes clear in chapter three of The Struggle to Create Post-Cold War Europe, while many East Germans who had protested against East Germany were indeed in favour of unification, others were sceptical. The idea of a 'third way' between socialism and capitalism was still alive in dissident circles.

Sarotte also takes seriously Gorbachev's ideas for ending the Cold War, calling his visions 'heroic' because they required an enormous outlay of trust not just on Gorbachev's part but also among his allies and opponents. At the same time, she shows how quickly events overtook Gorbachev's own planning and manoeuvring. The success of the West German Chancellor Helmut Kohl's allies in the March I990 elections in East Germany, which went beyond the expectations of Kohl himself, largely eliminated any vision for reunification or reform outside of the 'pre-fab' model of incorporating East Germany into a united Germany while retaining Western institutions, including the monetary system (I42-3). Similarly, by the spring of 1990 none of the Western powers seemed to feel any need to take Gorbachev's problems or needs into account.

This is where one of the most controversial episodes of the end of the Cold War comes in. Russian officials (and Gorbachev himself) have long insisted that in February I990 Moscow had been promised that after German reunification NATO would move 'not one inch eastward' (IIO-II). They cite NATO's later expansion into former Warsaw pact states like Poland and Hungary, and finally the Baltic states of Estonia, Latvia and Lithuania, as a violation of that agreement. Russia's policies in Ukraine, including its support of separatists after 20I4, have often been explained 
in this light. With the Warsaw Pact falling apart, this promise was probably the bare minimum that Gorbachev needed to assuage his conservative critics. (The dissolution of NATO would have been preferable.) The next day Gorbachev agreed to the proposition in a meeting with Kohl, but still without any assurances in writing. Sarotte, drawing in part on US materials that she received through Freedom of Information Act (FOIA) requests, shows that while US Secretary of State James Baker did indeed offer the possibility of such an assurance to Gorbachev in February I990, this was part of an evolving US position that had little support within the White House. As Bush told Kohl only a few days later at Camp David: 'to hell with that! We prevailed and they didn't. We can't let the Soviets clutch victory from the jaws of defeat' (227).

Sarotte's take on high-level politics at the end of the Cold War is thus different from that in the works by Service and Wilson, as well as from other recent historiography on the subject. ${ }^{15}$ Wilson and Service generally agree that the Bush administration, after pausing to reassess relations after taking over from Reagan in I989, largely sought to cooperate with the Soviet Union. The main obstacles to cooperation were domestic such as critics from both parties, as well as ethnic lobbies, who thought Bush was taking too soft a line. Economic aid was limited by chaos within the Soviet Union. In both of these accounts Bush administration officials recognised the historic nature of the moment and did not seek to overcapitalise on the Soviet Union's difficulties. Sarotte's account, however, suggests that triumphalism was already alive and well in I990, if not earlier. Although she is careful not to lend credence to Russian claims of betrayal, pointing out that Gorbachev is to blame for giving the game away, Sarotte suggests that American officials understood the balance of forces much better than their Soviet counterparts and saw an opportunity to lock in a US presence on the continent. $^{16}$

In any case, the nature of contemporary Russian complaints is ultimately not about the legal aspects of the agreement but rather the spirit. The fact that there was no formal promise not to expand NATO is ultimately less important than the idea that a spirit of cooperation was ultimately used to extend US power.

The books under review here give us a good sense of how the study of the end of the Cold War is beginning to consolidate, integrating more established political and diplomatic history approaches with a focus on transnational and non-state actors.

15 In The Last Empire: The Final Months of the Soviet Union, the historian Serhii Plokhy argued that the Bush administration had wisely avoided engaging in triumphalism in the final year of the Soviet Union, carefully avoiding any moves that might undermine Gorbachev. The seeds for triumphalism, according to Plokhy, were planted in January I992, when the president boasted in his State of the Union address that 'the Cold War did not end - it was won'. Serhii Plokhy, The Last Empire: The Final Days of the Soviet Union (New York: Basic Books, 2013), 389.

16 Drawing on yet more recently declassified information, Joshua R. Itzkowitz Shifrinson makes this point more strongly. See Joshua R. Itzkowitz Shifrinson, 'Deal or No Deal? The End of the Cold War and the U.S. Offer to Limit NATO Expansion', International Security, 4O, 4 (Spring 20I6), 7-44. As Itzkowitz-Shifrinson writes: 'Russian leaders are essentially correct in claiming that U.S. efforts to expand NATO since the I990s violate the "spirit" of the I990 negotiations: NATO expansion nullified the assurances given to the Soviet Union in I990’ (II). 
With new documents from the Reagan and George H.W. Bush administrations, as well as from European archives, likely to emerge in the coming years, scholars will surely continue to write histories that focus only on diplomats and policy makers. The most interesting work, however, will integrate approaches from diplomatic history and transnational history, while thinking about the role of domestic social movements and the economic transformations of the era.

An important lesson from these studies is that historians would do well to treat I989 less as an end and more as a mid-point to the world that took shape between the late I970s and the start of the next millennium. ${ }^{17}$ To this end, historians of the United States have generally done a better job of rethinking traditional periodisation, extending the story of the late Cold War back to the I970s and continuing it into the I990s. The story of Gorbachev's reforms and Eastern European transformations is heroic and irresistible for researchers of the Cold War but it cannot be understood without a deeper engagement with the political, economic and cultural history of the decades prior.

Looking forward, the hard work will fall to historians of the Soviet Union and the former socialist countries. For the first twenty years after I99I, historians of the Soviet Union had focused on the Stalin era; only recently have they begun to turn to the Khrushchev years and the period of 'late socialism' in earnest. The study of the Soviet Union's long I970s is still in its infancy. Scholars of Cold War history, meanwhile, rarely engage deeply in the domestic history of the Soviet Union. As a result, while there has been fascinating research on topics such as cultural exchange, tourism and youth cultures, the work has yet to inform studies of Soviet foreign policies in the way that work on the I970s has informed the understanding of the United States's place in the world in that era. Recent studies on political economy and trade in the socialist sphere during the I970s have shown the rich possibilities of situating the socialist and post-socialist world in the longue duree. ${ }^{18} \mathrm{~A}$ few historians, notably Sergey Radchenko and Christopher Miller, have shifted their focus away from Gorbachev and his opponents to analyse the broader challenges facing the Soviet Union in the I980s, the models available for reform and the social forces at play. ${ }^{19}$ Ironically, although historians generally assume that Gorbachev was forced to pursue reforms by the poor economic performance of the Soviet Union, real archival research on Soviet economics in the I980s and the history of economic reform is still in its infancy. In order to add something new to our knowledge of the collapse

17 A notable exception are Stephen Kotkin's books on the Soviet collapse and the fall of communism in Eastern Europe, but these book length essays hardly answer all the questions one can pose. See Stephen Kotkin, Armageddon Averted: The Soviet Collapse, 1970-2008 (Oxford: Oxford University Press, 200I, 2008); Kotkin, with a contribution by Jan T. Gross, Uncivil Society: 1989 and the Implosion of the Communist Establishment (New York: Modern Library, 2009).

18 See the special issue edited by Angela Romano and Frederico Romero, 'European Socialist regimes facing globalisation and European co-operation: dilemmas and responses', European Review of History, 2I, 2 (2OI4).

19 Sergey Radchenko, Unwanted Visionaries: The Soviet Failure in Asia at the End of the Cold War (Oxford: Oxford University Press, 20I4); Christ Miller, The Struggle to Save the Soviet Economy: Mikhail Gorbachev and the Collapse of the USSR (Chapel Hill: University of North Carolina Press, 20I6). 
of communism in Europe, we need to better understand the nature of economic ideas and reform, Soviet and East European engagement with global processes, and the dynamic political struggles that extended from the I970s to the I990s. Without taking the longer view we will soon run out of new things to say about the end of the Cold War, while still leaving many questions unanswered. 